\title{
British Imperialism and the Politics of Translation: Texts from, and from Beyond, the Empire
}

\section{NABANITA SENGUPTA}

\begin{abstract}
Tejaswini Niranjana suggests that translation both shapes and takes shape 'within the asymmetrical relations of power that operates under colonialism'. By suggesting this she rightly brings colonialism, translation and power politics together. Imperialist mission, which was essentially a play for power control went hand in hand with the project of translation and could not have been effectively carried out for over two centuries without it. Beginning with Niranjana's premise then shows that translation has to perform the dual role of shaping the colonial enterprise as well as being shaped by it. Translation has been used as a tool for invasion, specifically of the minds, by the imperialists. But even here there is a paradox inherent in its purpose. Though it has been undertaken by the West to further their colonial cause, often it has been seen that the translations from the West have brought about waves of nationalism as well as modernism in the literature of the colonial countries. This paper attempts to study the relationship that existed between Orientalism and translation in China the country of
\end{abstract}


the Far East, technically beyond the Empire; and India, the most important colony of the English in the Near East. The difference in the nature of imperialism in the countries of the Far East, who were never a direct colony of any Western power, and that of India also reveal a difference in the attitude of the West in the projects of translation that they undertook. Translations from Sanskrit that were undertaken had a very practical purpose behind them while most of the translations from Chinese and Japanese were taken up for the lure of their exoticism to the Western readers. Proximity with India also accounts for a greater and more organised enterprise of translations from Sanskrit into English than those from the other two languages, at least initially. In spite of certain differences in the attitude of the West in undertaking the translations of the literature of these countries, this entire activity has been given a common platform in the Oriental discourse by the snobbery of the West. Hence at the heart of such acts of translation the 'lack' in the native languages is always stressed upon and they are rendered deficient when compared with those of the West. Translations by the Christian missionaries mark the beginning of the epoch of translation in all these three countries. In fact it signifies the beginning of Western invasion as well as the enterprise of Oriental translation. The translation of popular literature is an affair of the modern times when the Western interest in colonialism started waning. This broadened the outlook of the Western litterateurs and they started looking towards the East for the sake of their interest in those cultures. Another important characteristic common to all these three linguistic communities is the impact of 
Western translation upon their literatures. A profusion of Western popular literature available in translation in these languages has led to the beginning of modernization in these literatures. The great impact of Western literature upon these cultures has been much more than the influence of the East on the Western literary traditions. The reason for it can be attributed to the constant and well-organized efforts by the West to maintain the hegemony of its discourse in the colonial East. Hence a study of the process of translation with respect to these three colonial countries and their relationship with the West proves that in spite of the difference in their political situations, the features of such translations remained more or less the same.

Tejaswini Niranjana suggests that translation both shapes and takes shape 'within the asymmetrical relation of power that operates under colonialism' (cited in Bassnett and Trivedi 1999: 3). In this paper I shall endeavour to show how this lop-sided cultural encounter associated with imperialism created the scope for translation even as it affected the translational strategies in the days of the early British Imperialists by drawing references from the two Asian countries where imperialism was effective in different degrees and modalities, viz. India, the most important colony of the British Empire, and China, a semi-colonial state where Britain's colonial ambition was thwarted more successfully.

The Chinese conception of the centrality of their Empire and the arrogance with which they tried to maintain it was a challenge to the West's construction of the myth of its racial superiority over the East. British colonial history speaks of a number of their futile attempts to enter the Chinese territory. In 1759, James Flint, a British emissary to the Chinese Emperor was arrested and 
imprisoned for breaking the Quing regulations, and amongst other charges, for having learnt Chinese! Again, in 1792-93, another British emissary, this time from King George the third, was sent back from China, unsuccessful in his attempt to gain an entry into the Chinese territory, with an answer that smacked of arrogance and racial pride. The emperor replied to the British Crown as:

\begin{abstract}
"We have never valued ingenuous articles nor do we have the slightest need of your country's manufactures, therefore $\mathrm{O}$ King, as regards to your request to send someone to remain at the capital, which it is not in harmony with the regulations of the Celestial Empire - we also feel very much that it is of no advantage to your country"
\end{abstract}

(Spencer 1990: 122)

This answer to the British Emperor shows the extent to which the Chinese preferred isolation from the West denying the Western powers their traditional initial foothold into any country, which is trade and commerce. Many such evidences of insularity practiced by China are present in Chinese history, which can be identified as a result of their extreme racial pride and a strong central government. On the other hand, the fall of the Mughals and the almost non-existence of a cohesive political structure made India easily accessible to the British Imperial power. Not facing any strong and unified opposition then, the English merchants, and later, the Crown could easily establish their hegemonic rule here.

This difference in the political status of the British Imperialists in India and China is deeply reflected in their attitudes towards the English translations from the Indian and the English translations from the Chinese languages. The nature and quality of the translations lead us to the conclusion that there is no engagement with the Chinese culture in the same sense as there is with the Indian culture, as I have tried to show here. 
The British imperialists had a very practical purpose behind translating Indian classics - the necessity to know the colonized in order to rule them more effectively. Hence as early as 1776, Governor-general Warren Hastings commissioned a group of Indian pundits to translate from the Dharmasastras which, he was informed were the law-books, into Persian and which was then retranslated into English by Halhead, one of the Orientalists. Thus began an epoch of the Western interest in the Indian classics. The first direct translation from Sanskrit to English was of the Bhagwadgita by Charles Wilkins (Wilkins 1785). The then Governor-General, Hastings, arranged for its publication and wrote a letter of introduction to it, which amply focuses on the nature and purpose behind such an endeavor. Wilkins also translated the fables from the Hitopadésa. William Jones translated a number of Sanskrit works into English, for example, Kalidasa's Sakuntala (1789), translations from the Laws of Manu (1794), etc. Many other Orientalists followed suit.

The different subjective position of the British Imperialists in China did not create any practical necessity to translate in the Chinese context. It did not therefore lead to the translations of any such works of law or philosophy into Western languages. Apart from two translations of a romantic Chinese novel into English, an anonymous one in 1761, followed by that of J.E. Davis, the earliest translations from Chinese were those of religious texts, generally undertaken by the missionaries, who were almost always, the heralds of imperialism unlike the Indian counterparts where the translations undertaken were more secular in nature and had a greater political approach. We thus have James Medhurst's translation of The Shoo King or the Historical Classics (1846) and James Legge's (1814-97) complete translation of the Confucian Analects and of some of the texts of Taoism. Samuel Beale, a naval chaplain, in about the 1850s translated various Buddhist works from the Chinese. Another 
important translator was Herbert Giles (1845-1935). His translations encompassed a wider area, selecting texts from Philosophy (e.g. Chuen Tza Mystic, Moralist and Social Reformer), poetry (e.g. Chinese Poetry in English Verses) and classical prose (Strange Stories from a Chinese Studio, Gems from Chinese Literature).

China was erased or suppressed in the Western consciousness up until Arthur Waley and Ezra Pound who come late in the History of British Imperialism, almost towards the decline of its colonial enterprise. But in the heydays of British colonialism, no parallel to, say, Arnold's engagement with India, in terms of a Western scholar's engagement with China could be found. It could be persuasively argued, then, that such erasure or suppression, almost a political parallel to that erasure of Annette Valon in The Prelude which Spivak has persuasively argued for in 'In Other Worlds', is a compensatory psychological mechanism for a repeated political and commercial failure to integrate China into the British Empire. Wolfgang Franke in his work China and the West reasons, "The West in the nineteenth and the twentieth century were lesser ready to understand China, than China was to understand the West" (Franke 1967: 140). This change in attitude came about more after the Treaty of Nankeen in which the balance tilted in West's favour and the Western missionaries got the protection from the Imperial masters. Since China was not a direct colony, the West was also saved from the administrative bothering, which was there in the case of India. Hence the English had absolutely no requirement to engage with Chinese language and culture. Though in the mid eighteenth century, Voltaire and some of his contemporaries had found a source of profound wisdom in China; this interest was really short lived. What is not translated is dismissed as trivial or unworthy. Paradoxically, however, this establishes a similarity also with India because what is conquered is equally dismissed as trivial or unworthy. 
The fact that Chinese literature, in spite of having a long and rich history, remains for so long out of the reach of the West is as much a result of the West's failure to integrate it as a part of its colonial property, as also of China's xenophobic tendencies which isolated it from the rest of the world. Some Chinese policies like kowtowing before the Emperor were injurious to the British sense of dignity and this also forced these foreigners to remain away from China for quite a long time. Conversely then, the growing interest of the British in Indian philosophy and literature is closely related to the rise in the English colonial engagements in India.

A study of the English translations of both these countries reveal another major difference in the attitudes of both these countries - a profusion of attempts by the Indians to render their texts in English translations is starkly contrasted with an absence of any such endeavors in China. The response of the Indians to represent their works in English translation is an evidence of a complex psychology of the colonized. On the one hand there is obviously the desire to earn approbation from their Western masters by presenting their literature in English, but on the other hand, a xenophobic tendency can also be discerned which attempts to dislodge the Western notion of its superiority by giving them a taste of the Indian antiquities. China, not having a long colonial history at its back and being able to check Western invasion with considerable success, was free from this muddling psychological complexity. Not only that, Western language, culture or literature was also largely ignored by the Chinese, because of the latter's contempt for Christianity and everything associated with it. Even after the May Fourth Movement, when they started translating Western classics finally into English, the desire to render their own work into any European language is surprisingly absent.

Contrastingly, the desire amongst the Indians to translate their indigenous works into English marks the beginning of a new 
epoch of translation in India, which was preceded by an age of British, or European monopoly as translators of the Indian texts into Western languages. It was Tagore's winning of the Nobel Prize in 1913, which symbolised the recognition of the intellectual capacities of the East by the West, and which spurred the Indian efforts towards the renderings of their own texts in English.

In spite of the difference in the terms of the texts translated from the Indian and the Chinese and in the quality and ideology of these translations, certain parallels can be drawn between the English translations from the literature of both these countries. Almost always, the colonialist's translations were from the texts belonging to the ancient past of the colonies - from which they could unearth gems of the ancient wisdom, for example, both Confucian texts as well as the Gita appealed to the West for their philosophies. This tendency amongst the early imperialists, to find seeds of wisdom in the texts of the past is a strategy to negate or suppress the 'present' in the colonies which is necessary to maintain the position of ideological supremacy and also to give validity to their selfconstructed doctrine of the 'white man's burden', their attitude being to restore the East from its current fallen state by the means of Western enlightenment. Contrastingly, however, the books translated from European into either Chinese or Indian languages are always those belonging to the contemporary period or otherwise, the Bible, further validating the notion of the enlightened West and the dark East. Robert Morrison in 1823 made the Bible available to the Chinese by translating it in their language and in the Indian context this task was undertaken much earlier, by William Carey, the missionary who tried to make the text available to the Indians in a number of regional languages and also helped establish The Bible Society of India in 1811. Some of the books that had been translated from English into Chinese by the native scholars in the early phase of such translations are Thomas Huxley's Evolution and Ethics (Trans. 1894-95), Adam Smith's The Wealth of Nation (Trans. 1897- 
1901, pub. 1901), John S. Mill's On Liberty (Trans. 1899, pub. 1903), etc.

In both these countries, such translations as well as the study of the original Western classics had a great impact on the indigenous form, content and literature. One such example in the Indian context is the sonnet form introduced in Bengali literature by Michael Madhusudan Dutt. Indigenous Chinese literature too underwent a sea change in both form and content under the influence of the Western literature, though in their case, unlike their Indian counterpart, English was not the only dominating influence. Russian, German and other Western literature too asserted their own presence in the form of the translated works. The introduction of English teaching into the Indian education system, which was actually done to cater to the ruling country's need for the English knowing native intelligentsia for the smooth running of the administrative machinery, equipped the Indians to read the English classics in their original forms though translations were also made available in a number of cases. China did not have any such direct access to Western literature.

Wolfgang Franke says the following in his work China and the West:

"because of the exclusive orientation towards Europe of the Western academic study, Oriental civilizations were studied in the first instance purely on the basis of their importance for the civilization of the West"

(Franke 1967: 145)

Sanskrit, therefore, occupies an important place in Western scholarship by virtue of it being considered to be an Indo-European language by Europeans. Similarly Confucianism drew Western attention for the similarity that the West could trace between it and 
early Christianity. It is thus not just intercultural diversity that is necessary, but also a certain amount of cultural and morphological similarity, to generate and sustain the interest in translation from one language to another.

This factor of diversity also worked as a hindrance to translation from Chinese to English, as the language itself appeared to be 'formidable' and 'bewildering' to the West, 'rendering the problems of equivalence among the languages almost absurd' (Schwab 1984: 6) The orientalist, E.D. Ross recommended the study of the Chinese language because 'it is fascinating to try and puzzle out, say the writing on... a Chinese tea-set' (Schwab 1984: 20). The written Chinese characters generally represented the meanings of the word rather than its pronunciation, while in the Roman as well as in the Indian scripts the characters represented sounds, which formed different combinations to make different words having particular meanings. Therefore translation of Chinese works, particularly poetry, became a matter of great difficulty. Much later when Arthur Waley took up the task of translating from Chinese, he had to find a way to deal with this problem. The solution that he arrived at was the use of sprung rhythm in the English versions of the poems. As the entry on Waley in the Encyclopedia of Literary Translation into English says,

"In the Chinese original, the rhythm in a given line is dependent on the alteration between syllables, each unit distinguished by a different 'tone' quality. English, on the other hand, is an accented language. To solve this problem, Waley adopted 'sprung rhythm'... he tried to have the number of stressed syllables per English lines equal to the number of syllables in a Chinese line, disregarding the number of unstressed syllables within".

(Classe 2000: 96) $^{2}$ 
Lack of any motive apart from the curiosity in the exoticism of the pictorial script of the Chinese led to a dearth of Western interest in the Chinese language. Curiosity formed a part of their engagement with Indian literature as well, as Warren Hastings wrote in the letter to the Chairman of the East India Company, forwarding Wilkins's translation of the Gita: "I presume to offer, and to recommend through you, for an offering to the public, a very curious specimen of the literature, the mythology, and the Morality of the ancient Hindus" (Wilkins 1785: 5). According to Sharpe, this introduction was particularly necessary because Hastings "knew very well that a philosophical discourse was unlikely to appeal to the hard-headed businessmen who administered 'John Company' ". (Sharpe, 6)

The politics of translation operating in the age of colonialism signals that cultural relativity is not the only factor that determines either quality or quantity of the texts translated. The position of the imperial power in the dominated countries and the extent of direct engagement with the colonies play an important role in determining its translational strategies. What gets translated and how is a result of the coloniser's need to represent, suppress, or erase the colonial presence in order to maintain its political, economic and ideological supremacy. On the other hand, translatability is also affected by the colonised's engagement with this act of translation itself and this is clearly reflected by the difference in the attitudes of the Chinese and the Indians towards their translations of their literature into English or any other Western language. India was part of the Empire and China was beyond it. Translation between the English and Chinese languages (in either direction) and those between English and Indian languages are amply shaped by and reflects this empirical fact. 


\section{NOTES}

1. A detailed knowledge of Western books translated into Chinese and their impact on Chinese society and literature is available in Chow Tse-tsung's The May Fourth Movement: Intellectual Revolution in Modern China, Chapter XI.

2. Such a rendering of Chinese verses into English mars the readability of the original as is evident from the following sample of poetry, a poem traditionally attributed to Chü Yüan of the third or second century B.C., selected from the vast oeuvre of Waley's works:

The Great Summons

Invocation to the soul of a dead or sick man

Green Spring Receiveth

The vacant earth;

The white sun shineth;

Spring wind provoketh

To burst and burgeon

Each sprout and flower.

The dark ice melts and moves; hide not, my soul!

O Soul, come back again! O do not stray!

O Soul, come back again and go not east or west, north or south!

For to the East a mighty water drowneth Earth's other shore;

Tossed on its waves and heaving with its tides

The hornless Dragon of the Ocean rideth;

Clouds gather low and fogs unfold the sea

And gleaming ice drifts past.

O Soul, go not to the East,

To the silent Valley of Sunrise! 


\section{REFERENCES}

Bassnett, Susan and Harish Trivedi (1999) Post-colonial Translation: Theory and Practice. London and New York: Routledge.

Classe, Olive (ed.) (2000) Encyclopedia of Literary Translation into English. London and Chicago: Fitzroy Dearborn Publishers.

Chow Tse-tsung. (1960) The May Fourth Movement: Intellectual Revolution in Modern China. Cambridge and Massachusetts: Harvard University Press.

Franke, Wolfgang. (1967) China and the West R.A.Wilson (Trans.). Oxford: Basil Blackwell.

Morris, Ivan. (1970) Madly Singing in the Mountains: An Appreciation and Anthology: Arthur Waley. London, George Allen and Un Win Ltd.

Ross, E.D. (1928) Eastern Art and Literature: with special reference to China, India, Arabia and Persia London: Benn's Sixpence Library.

Schwab, Raymonds. (1984) The Oriental Renaissance: Europe's Rediscovery of India and the East, 1680-1880. Gene Patterson-Black and Victor Reinking. (Trans.). New York: Columbia University Press,

Spencer, Jonathan D. (1990) The Search for Modern China London, Sydney, etc.: Hutchinson 
Wilkins, Charles. (1785) The Bhagwat-Geeta or Dialogues in Eighteen Lectures with Notes (Translated from the original, In the Sanskrit Language of the Brahmanas). London: C: Nourse. 
